\title{
Pengaruh Pemberian Salep Kombinasi Ekstrak Daun Morinda citrifolia dan Batang Euphorbia tirucalli terhadap Penyembuhan Luka
}

Reza Pertiwi ${ }^{1}$, Syalfinaf Manaf $^{2}$, Rochmah Supriati ${ }^{2}$, Hari Marta Saputra ${ }^{2}$, Fitri Ramadhanti ${ }^{3}$

${ }^{1}$ Program Studi S1 Farmasi, Fakultas Matematika dan Ilmu Pengetahuan Alam, Universitas Bengkulu, Bengkulu Indonesia

${ }^{2}$ Jurusan Biologi, Fakultas Matematika dan Ilmu Pengetahuan Alam, Universitas Bengkulu, Bengkulu, Indonesia

${ }^{3}$ Rumah Sakit Umum Daerah Tais, Kabupaten Seluma, Provinsi Bengkulu, Indonesia

*Corresponding author: rpertiwi@unib.ac.id

Submitted: 16 Maret 2020

Accepted: 5 Mei 2020

Published: 25 Juni 2020

\begin{abstract}
Background: Wound healing is a process of replacing dead or damaged tissue through the process of cell regeneration. The branches of Euphorbia tirucalli contains alkaloids, flavonoids, saponins, and tannins, while Morinda citrifolia contains alkaloids, tannins, saponins, flavonoids, and triterpenoids. The ability of ointment combination of Morinda citrifolia leaves extract and the stem of Euphorbia tirucalli can accelerate wound healing. Objective: This study aimed to determine the effective formulation and the effect of ointment combination extract on Morinda citrifolia leaves and the stem of Euphorbia tirucalli extracts on the healing of rats' superficial incision wound. Methods: 28 male white rats divided into 7 treatment groups. Group K (-) without treatment, group $\mathrm{K}(+)$ given Povidone Iodine 10\%, F1 with ointment of Euphorbia tirucalli stem extract, $F 2$ with ointment Morinda citrifolia leaf extract, $P 3$ with ointment combination Morinda citrifolia leaves and Euphorbia tirucalli stem 0.75:0.25; F4 with ointment combination Morinda citrifolia leaves and Euphorbia tirucalli stem extract 1:1, and F5 giving ointment combination with Morinda citrifolia leaves and Euphorbia tirucalli stem 0.25:0.75. Histopathology observation of incised wound skin was descriptively analyzed by comparing the treatment and the control group. Results: Formulation III is the effective formulation where on the 5th and 6th day the wound started to close while on the 7th and 8th day the wound completely closed. Conclusion: The use of ointment formulations affects the regeneration of superficial incision wound healing cells through the inflammatory phase, TNF- $\alpha$, re-vascularization, and proliferation phase.
\end{abstract}

Keywords: Euphorbia tirucalli, Morinda citrifolia, wound healing, superficial incision wound healing

Abstrak
Pendahuluan: Penyembuhan luka adalah proses terjadinya penggantian jaringan yang rusak atau mati dengan
jaringan yang baru melalui proses regenarasi sel. Ranting Euphorbia tirucalli mengandung alkaloid, flavonoid,
saponin, dan tannin, sedangkan Morinda citrifolia memiliki kandungan alkaloid, tanin, saponin, flavonoid serta
triterpenoid. Kemampuan kandungan dari kombinasi salep ekstrak daun Morinda citrifolia dan batang Euphorbia
tirucalli diduga dapat mempercepat penyembuhan luka dan periode fibroblas, neovaskularisasi dan epitelisasi.
Tujuan: Penelitian ini bertujuan untuk mengetahui formulasi salep yang efektif dan pengaruh salep kombinasi
ekstrak daun Morinda citrifolia dan batang Euphorbia tirucalli terhadap penyembuhan luka insisi dangkal pada
tikus. Metode: Sebanyak 28 ekor tikus jantan dibagi kedalam 7 kelompok perlakuan. Kelompok K(-) tanpa
perlakuan, kelompok K(+) dengan pemberian Povidon Iodine 10\%, F1 dengan pemberian salep kombinasi
ekstrak batang Euphorbia tirucalli, F2 dengan pemberian salep ektrak daun Morinda citrifolia, F3 dengan
pemberian salep kombinasi ekstrak daun Morinda citrifolia dan batang Euphorbia tirucalli perbandingan
0,75:0,25; F4 dengan pemberian salep kombinasi ekstrak daun Morinda citrifolia dan batang Euphorbia tirucalli
dengan perbandingan 1:1 dan F5 dengan pemberian salep kombinasi ekstrak daun Morinda citrifolia dan batang
Euphorbia tirucalli perbandingan 0,25:0,75. Pengamatan histopatologi kulit tikus dianalisis secara deskriptif 
dengan membandingkan antara kelompok kontrol dan kelompok perlakuan. Hasil: Formulasi salep yang efektif adalah formulasi III dimana hari ke-5 dan hari ke-6 luka sudah mulai menutup sedangkan pada hari ke-7 dan 8 luka sudah menutup. Kesimpulan: Pemberian salep kombinasi daun Morinda citrifolia dan batang Euphorbia tirucalli efektif dalam menyembuhkan luka insisi dangkal melalui fase inflamasi, TNF- $\alpha$, re-vaskularisasi dan fase proliferasi.

Kata kunci: Euphorbia tirucalli, Morinda citrifolia, penyembuhan luka, luka insisi dangkal

\section{PENDAHULUAN}

Penyembuhan luka adalah proses terjadinya penggantian jaringan yang rusak atau mati dengan jaringan yang baru melalui proses regenerasi sel. Proses penyembuhan dari sel parenkim dengan mengganti sel yang rusak dengan sel yang baru dan sama sehingga fungsi tubuh atau jaringan akan pulih kembali dengan sempurna dikenal sebagai regenerasi. Proses yang kemudian terjadi pada jaringan yang rusak tersebut ialah proses penyembuhan dan regenerasi sel yang terjadi sebagai respon fisiologis tubuh. Proses penyembuhan luka terdiri dari tiga fase yaitu inflamasi, proliferasi atau granulasi dan fase remodeling (Sjamsuhidajat \& Jong, 2010).

Fase inflamasi merupakan reaksi awal bila tubuh terkena luka (Ambiyani, 2013). Fase ini terjadi segera setelah cedera dan dapat berlangsung sampai 4 - 6 hari (Broughton dkk., 2006). Fase proliferasi dimulai setelah respon akut dari hemostasis dan inflamasi mulai berhenti, ancang-ancang perbaikan luka mulai dilakukan dengan angiogenesis, fibroplasia dan epitelisasi. Fase ini dimulai sekitar hari ketiga yang ditandai dengan peningkatan drastis dari koloni sel dan produksi kolagen. Produksi kolagen sebenarnya telah dapat dideteksi mulai sepuluh jam setelah trauma, mencapai puncaknya pada hari ketujuh, dimana luka telah terisi penuh oleh jaringan kolagen (Lawrence \& Lowenstein, 2001). Fase Remodeling merupakan fase terpanjang penyembuhan luka yaitu pematangan proses, yang meliputi perbaikan yang sedang berlangsung pada jaringan granulasi yang membentuk lapisan epitel yang baru dan meningkatkan tegangan pada luka (Ueno dkk., 2006).

Penanganan luka dapat dilakukan dengan memberikan antiseptik, antibiotik, dan perawatan luka pada umumnya dengan pemberian povidone iodine yang berfungsi sebagai antiseptik yang dapat membunuh mikroorganisme seperti bakteri, jamur, virus, protozoa, dan spora bakteri (Putra, 2016).

Mengkudu adalah satu dari tanaman tropikal yang memiliki kandungan senyawa metabolit sekunder tannin, alkaloid, saponin, flavonoid serta triterpenoid (Soni \& Singhai, 2012). Pada kulit, flavonoid dapat menghentikan pendarahan dari luka dan meningkatkan aktivitas vitamin C sebagai antioksidan (Nabilla, 2014). Tanin dan saponin diketahui juga berperan sebagai antimikroba dan antioksidan, meningkatkan kontraksi luka dan meningkatkan kecepatan epitelisasi (Thakur dkk., 2011). Daun segar mengkudu secara tradisional dikonsumsi sebagai obat untuk patah tulang, luka sayat, luka bakar dan nyeri (Rasal dkk., 2008).

Batang Euphorbia tirucalli mengandung glikosida, saponin, dan asam elagat (Dalimartha, 2003), ranting patah tulang mengandung senyawa alkaloid, flavonoid, saponin dan tanin (Absor, 2006). Senyawa aktif dari Euphorbia tirucalli yaitu saponin yang dapat mempengaruhi kolagen dengan menghambat produksi jaringan luka yang berlebihan sebagai tahap awal perbaikan jaringan (Setyoadi \& Sartika, 2010). Senyawa aktif tanin juga berpengaruh dalam penyembuhan luka yang bermanfaat sebagai astringent (Suprapto, 2012).

Kemampuan kombinasi salep kombinasi ekstrak daun mengkudu dan batang patah tulang diduga dapat mempercepat penutupan luka dan periode fibroblas, neovaskularisasi dan epitelisasi yang belum terungkap secara ilmiah sampai saat ini, sehingga penelitian ini dilakukan untuk mengetahui efektivitas kombinasi ekstrak daun mengkudu dan batang patah tulang bentuk formulasi salep dalam mempercepat kesembuhan luka sayat tikus jantan melalui penutupan luka dan periode fibroblas, neovaskularisasi dan epitelisasi.

\section{BAHAN DAN METODE Bahan}

Bahan yang digunakan adalah ekstrak daun mengkudu, ekstrak batang patah tulang, Alkohol $70 \%$, etanol $96 \%$, Povidon Iodine $10 \%$, vaselin album, adeps lanae, Aquades, formalin 10\%, etanol 96\%, 90\%, 80\%, $70 \%, 60 \%, 50 \%, 40 \%, 30 \%$, etanol absolut 1 , alkohol absolut 2, blok paraffin I dan II, xylol I, II, III, IV, V, kaca objek, kaca penutup, HE, canada balsem, kain 
kasa, makanan dan minum standar untuk tikus, air panas, serbuk $\mathrm{Mg}, \mathrm{HCl}$ pekat, larutan $\mathrm{FeCl}_{3} 10 \%, \mathrm{HCl}$ $2 \mathrm{~N}$, kertas saring, aluminium foil, kloroform.

Alat

Alat yang digunakan adalah kandang tikus, timbangan analitik, gelas ukur, waterbath, saringan, blender, sarung tangan, cuttonbud, batang pengaduk, gunting, mata pisau, alat cukur, kamera digital, blok parafin, mikrotom, inkubator, mikroskop trinokuler, pipet volumetrik, tabug reaksi, mortar, sutil, lempeng kaca, killing bottle.

\section{Metode}

\section{Pembuatan ekstrak daun mengkudu}

Daun mengkudu yang masih segar dipilih dan dikumpulkan sebanyak $1 \mathrm{Kg}$. Ektraksi dilakukan dengan cara maserasi dengan menggunakan pelarut etanol $96 \%$.

\section{Pembuatan ekstrak batang patah tulang}

Pembuatan ekstrak batang patah tulang dengan mengambil batang patah tulang yang muda sebanyak 1 Kg. Batang patah tulang yang sudah kering diblender dan diekstrak dengan metode maserasi menggunakan pelarut alkohol $70 \%$.

\section{Formulasi salep kombinasi ekstrak daun mengkudu} dan batang patah tulang

Formulasi salep dibuat dengan mengacu pada formulasi dari Akhtar dkk. (2014) dalam Rakhim (2016) yang kemudian dimodifikasi. Dosis ekstrak yang digunakan dalam formulasi salep yaitu $10 \%$. Sediaan salep dibuat menjadi 5 formulasi berbeda dengan variasi konsentrasi ekstrak daun mengkudu dan batang patah tulang dapat dilihat pada Tabel 1.

Tabel 1. Formulasi sedian salep kombinasi ekstrak daun mengkudu dan batang patah tulang

\begin{tabular}{cccccc}
\hline Komposisi & \multicolumn{5}{c}{ Formulasi salep (gram) } \\
\cline { 2 - 6 } & F1 & F2 & F3 & F4 & F5 \\
\hline Ekstrak daun mengkudu & 0 & 2,0 & 1,5 & 1 & 0,5 \\
Ekstrak batang patah tulang & 2,0 & 0 & 0,5 & 1 & 1,5 \\
Vaselin album & 15,3 & 15,3 & 15,3 & 15,3 & 15,3 \\
Adeps lanae & 2,7 & 2,7 & 2,7 & 2,7 & 2,7 \\
\hline Jumlah & & &
\end{tabular}

*F1: Formulasi salep ekstrak batang patah tulang; F2: Formulasi salep ekstrak daun mengkudu; F3: Formulasi salep kombinasi ekstrak daun mengkudu dan batang patah tulang perbandiangan 0,75:0,25; F4: Formulasi salep kombinasi ekstrak daun mengkudu dan batang patah tulang perbandingan 1:1; F5: Formulasi salep kombinasi ekstrak daun mengkudu dan batang patah tulang perbandingan $0,25: 0,75$.

\section{Preparasi tikus jantan}

Penelitian ini menggunakan hewan coba berupa tikus jantan (Rattus novergicus) Sprague Dawley sebanyak 28 ekor yang terbagi dalam 7 kelompok perlakuan. Bulu daerah punggung tikus dicukur sampai licin, kemudian dibersihkan menggunakan kapas beralkohol 70\%. Setelah itu, punggung tikus dilukai menggunakan mata pisau yang steril, sepanjang $1 \mathrm{~cm}$ sedalam $0,2 \mathrm{~cm}$.

Pemberian formulasi salep kombinasi ekstrak daun mengkudu dan ektrak batang patah tulang

Pemberian salep berdasarkan pada formulasi salep dengan ekstrak daun mengkudu dan batang patah tulang yang terdiri dari:

1. Kelompok 1 (K-) adalah kelompok yang merupakan kontrol negatif tanpa pemberian perlakuan.

2. Kelompok $2(\mathrm{~K}+)$ adalah kelompok yang merupakan kontrol positif dengan pemberian Povidon Iodine 10\% sebanyak 2 tetes.
3. Kelompok 3 (P1) adalah kelompok yang diberi salep dengan ekstrak batang patah tulang.

4. Kelompok 4 (P2) adalah kelompok yang diberi salep dengan ekstrak daun mengkudu.

5. Kelompok 5 (P3) adalah kelompok tikus jantan yang diberi salep dengan perbandingan ekstrak daun mengkudu dan batang patah tulang 0,75:0,25.

6. Kelompok $6(\mathrm{P} 4)$ adalah kelompok tikus jantan yang diberi salep dengan perbandingan ekstrak daun mengkudu dan batang patah tulang 1:1.

7. Kelompok 7 (P5) adalah kelompok tikus jantan yang diberi salep dengan perbandingan ekstrak daun mengkudu dan batang patah tulang 0,25:0,75.

Pemberian perlakuan dilakukan 2 kali sehari (pagi dan sore) dan pengamatan luka dilakukan sekali sehari.

\section{Pembuatan preparat histopatologi}

Pembuatan preparat histopatologi dengan pengambilan sampel organ kulit tikus pada hari ke 2 dan 8 yang dipotong sampai dengan subkutan dengan 
ketebalan kurang lebih $3 \mathrm{~mm}$ dan panjang $2 \mathrm{~cm}$. Semua hewan percobaan dieuthanasia dengan killing bottle. Daerah punggung yang diambil kulitnya, dibersihkan terlebih dahulu dari bulu yang mulai tumbuh kembali.

Kulit dimasukkan dalam kain kasa, didehidrasi dan direndam dalam larutan etanol bertingkat yaitu $70 \%$, $80 \%, 90 \%, 100 \%, 100 \%$ dan $100 \%$ masing-masing selama 60 menit pada suhu kamar, Proses selanjutnya dilakukan penjernihan (clearing) menggunakan xylol selama 15 menit pada suhu kamar sebanyak tiga kali. Setelah proses clearing dilakukan proses infiltrasi dengan parafin cair sebanyak 3 kali pemidahan masingmasing 60 menit dalam inkubator suhu $60^{\circ} \mathrm{C}$. Jaringan kemudian dibenamkan dalam parafin cair dan didinginkan dalam suhu kamar sehingga menjadi blok parafin. Selanjutnya dilakukan proses embedding dan pemotongan dengan mikrotom arah horisontal dengan ketebalan $3 \mu$. Pengecatan toluidin blue dilakukan dengan prosedur sebagai berikut : parafin dihilangkan dengan $x y l o l$, kemudian dimasukkan dalam etanol $100 \%$, 95\% dan $70 \%$ masing-masing selama 5 menit, kemudian dimasukkan dalam aquades. Pengecatan dengan toluidin blue selama 40-60 menit dalam oven suhu $600^{\circ} \mathrm{C}$, kemudian dimasukan ke dalam etanol $70 \%$, 95\% dan $100 \%$. Setelah diberi Canada balsam ditutup dengan dek glass (Ahmad, 2009).

\section{Pengamatan histopatologi}

Pengamatan histopatologi kulit luka insisi dangkal tikus dilakukan dengan pengambilan sampel organ kulit tikus pada hari ke 2 dan 8 yang dipotong sampai dengan subkutan dengan ketebalan kurang lebih $3 \mathrm{~mm}$ dan panjang $2 \mathrm{~cm}$. Semua hewan percobaan dieuthanasia dengan killing bottle. Daerah punggung yang diambil kulitnya, dibersihkan terlebih dahulu dari bulu yang mulai tumbuh kembali.

\section{Analisis data}

Hasil histopatologi yang diperoleh dalam penelitian ini dianalisis dengan membandingkan antara kelompok kontrol dan kelompok perlakuan secara deskriptif.

\section{HASIL DAN PEMBAHASAN}

Penanganan luka insisi dengan menggunakan bahan yang terdapat di alam dapat dibuat dalam sediaan salep yaitu salep kombinasi ekstrak daun mengkudu dan batang patah tulang. daun mengkudu dan batang patah tulang terdapat senyawa aktif metabolit sekunder berupa saponin, flavonoid dan tannin yang berperan dalam penyembuhan luka.

Saponin dapat merusak permeabelitas membran yang mengakibatkan dinding sel bakteri rusak atau hancur sehingga saponin diduga memiliki kemampuan sebagai antibakteri dan antiseptik (Absor, 2006). Flavonoid juga diduga mempunyai kemampuan sebagai antibakteri karena kemampuannya yang dapat merusak susunan perubahan mekanisme permeabilitas pada dinding sel bakteri yang terjadi pada luka, selain itu flavonoid disebut sebagai antiseptik dan memiliki aktivitas biologis seperti antioksidan (Djamil dkk., 2012). Tanin diduga mempunyai kemampuan sebagai astringent, antioksidan dan antibakteri (Absor, 2006).

Pengamatan hari ke-2 (Gambar 1) histopatologi kulit tikus luka insisi dangkal setelah perlukaan ini terjadi fase inflamasi respon seluler, pada bagian lapisan epidermis terlihat epitel rusak dan dilapisan dermis terlihat fibroblas. Fibroblas yang terdapat pada kelompok kontrol negatif belum terlihat secara jelas sedangkan pada kontrol positif fibroblas sudah terlihat secara jelas dan fibroblas pada kelompok kontrol positif lebih banyak daripada fibroblas kelompok perlakuan. Hal ini dimungkinkan karena fase inflamasi berjalan normal (0-3 hari), tidak mengalami gangguan, dan fungsi dari sel-sel yang berperan pada respon seluler, termasuk perangsangan terbentuknya berbagai Growth Factor tidak terhambat, sehingga dapat meneruskan kepada fase selanjutnya (fase proliferasi) dengan cepat pada kelompok kontrol positif maupun kelompok kontrol. 

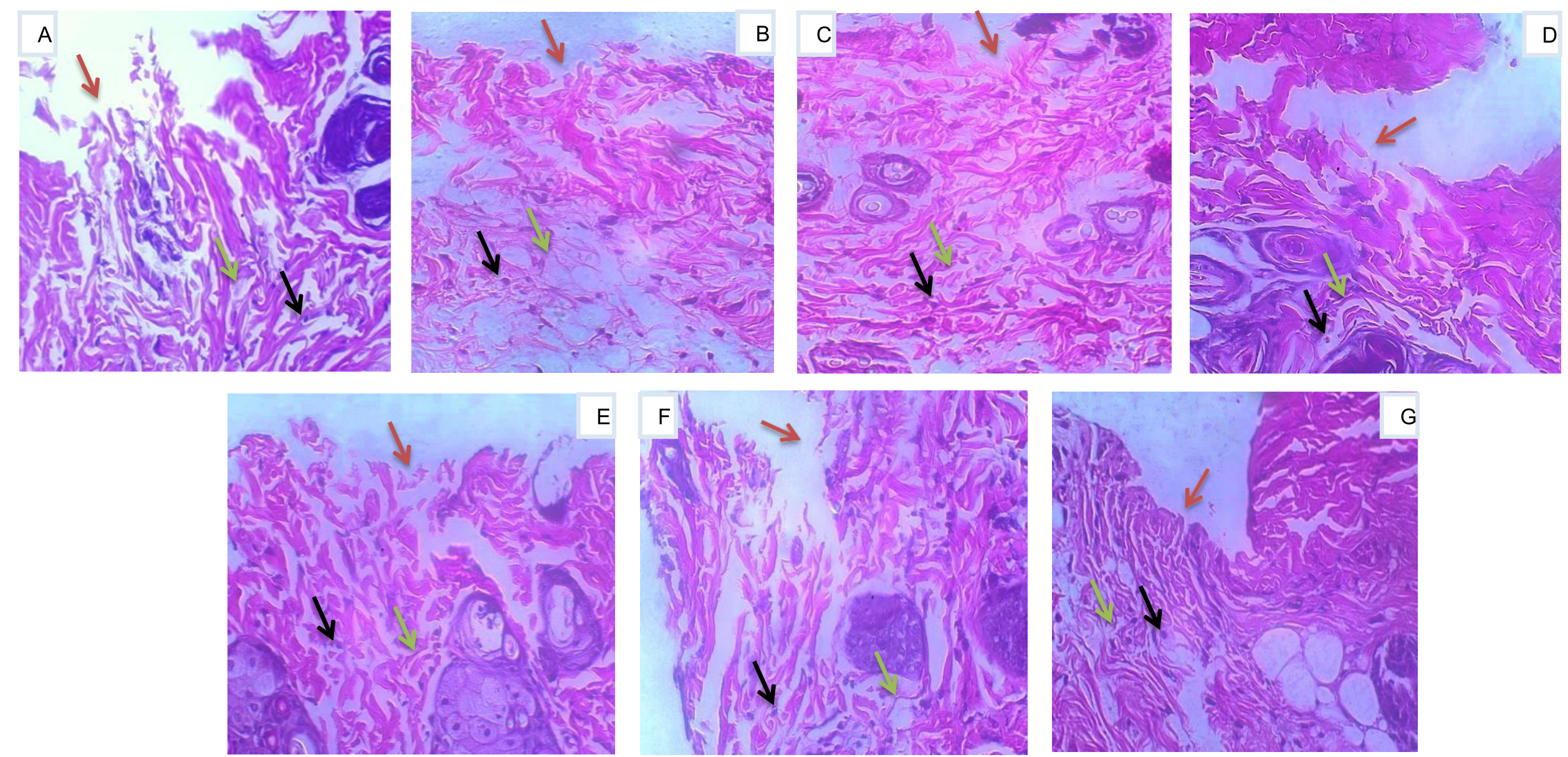

Gambar 1. Histologi kulit tikus luka insisi dangkal hari ke-2 hasil pewarnaan HE (400x) $: \rightarrow$ Epidermis yang rusak, $\rightarrow$ fibroblas, $\rightarrow$ neovaskularisasi. A) kontrol negatif, B) kontrol positif, C) formulasi I, D) formulasi II, E) formulasi III, F) formulasi IV, G) formulasi V 

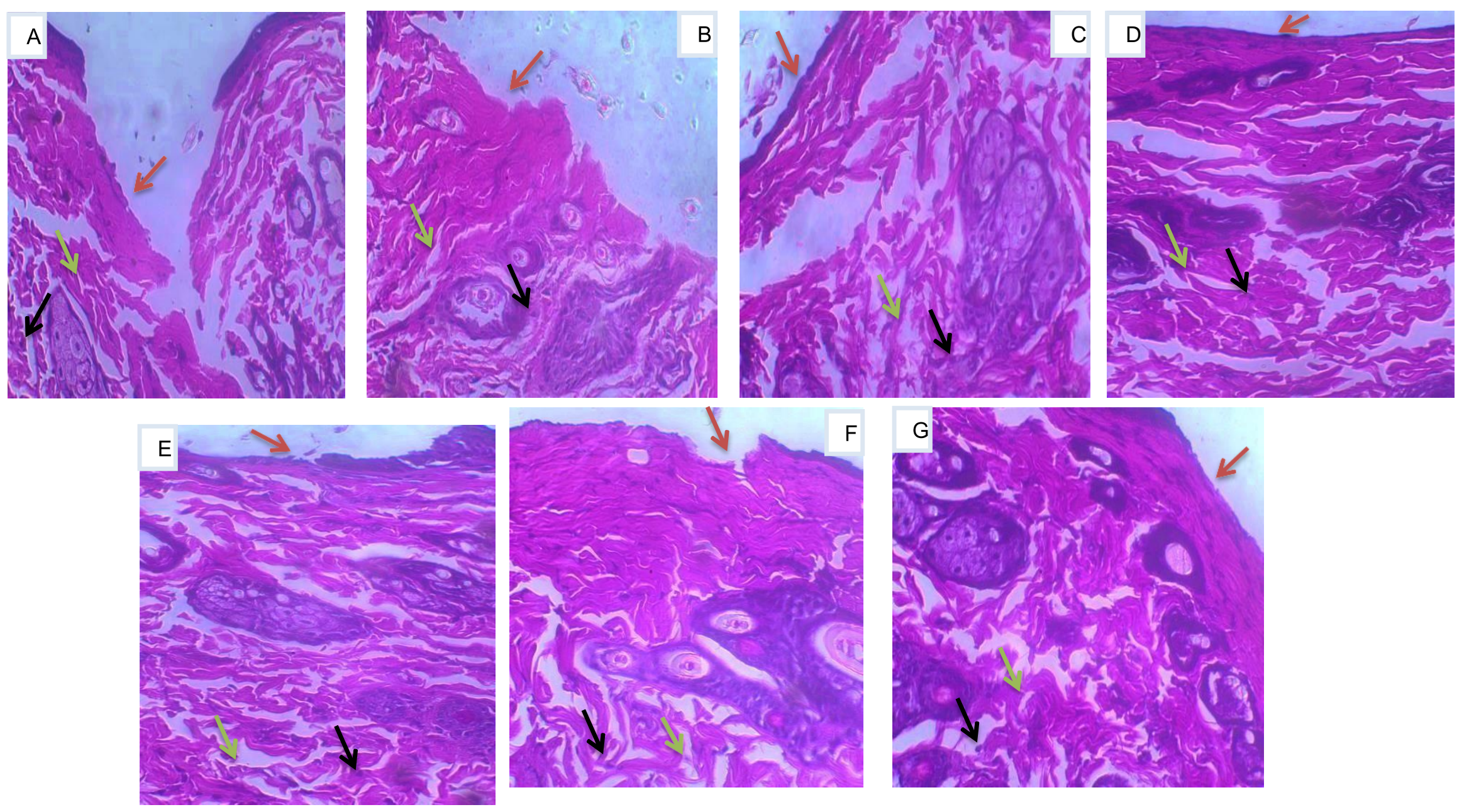

Gambar 2. Histologi kulit tikus luka insisi dangkal hari ke-8 hasil pewarnaan HE (400x) : $\rightarrow$ epidermis yang rusak $\rightarrow$ fibroblas, $\rightarrow$ neovaskularisasi. A) kontrol negatif, B) kontrol positif, C) formulasi I, D) formulasi II, E) formulasi III, F) formulasi IV, G) formulasi V 
Penggunaan basis salep yaitu vaselin album dan adeps lanae diketahui dapat membantu perbaikan luka. Hal ini dikarenakan sifat adeps lanae yang membantu penyerapan zat aktif untuk dapat masuk ke kulit, sedangkan vaselin album membantu salep untuk dapat bertahan lama dikulit sehingga penyerapan zat aktif dapat maksimal (Sentat \& Permatasari, 2015).

Pengamatan hari ke-8 (Gambar 2) histopatologi kulit tikus luka insisi dangkal setelah perlukaan terjadi fase proliferasi yang ditandai dengan jaringan dermis yang sudah mulai terinvasi dan terbentuknya epitelisasi, pada bagian lapisan epidermis terjadi proses epitelisasi kecuali pada kelompok kontrol negatif dan pada bagian lapisan dermis sudah terinvasi dengan jaringan granulasi. Epitel yang terdapat pada kelompok kontrol negatif belum mengalami epitelisasi dan masih terlihat celah luka, namun jaringan dermis sudah mulai terinvasi oleh jaringan granulasi, pada kelompok kontrol positif belum terlihat epitel tumbuh namun pada bagian epidermis bawah sudah mulai terinvasi dan pada bagian dermis sudah terinvasi oleh jaringan granulasi sedangkan pada kelompok perlakuan dengan fomulasi I, epitel sudah mengalami epitelisasi tetapi jaringan dermis belum sepenuhnya terinvasi oleh jaringan granulasi, pada kelompok perlakuan dengan formulasi II, IV dan V, epitel sudah mengalami epitelisasi namun belum sempurna dan jaringan dermis telah sepenuhnya terinvasi oleh jaringan granulasi, pada kelompok perlakuan dengan formulasi III, epitel sudah mengalami epitelisasi yang mendekati sempurna dan jaringan dermis telah sepenuhnya terinvasi oleh jaringan granulasi. Keadaan ini karena adanya berbagai antioksidan kuat ditambah dengan antibakteri yang terdapat pada daun mengkudu dan batang patah tulang, membantu fase inflamasi berjalan normal dan mempercepat terjadinya fase proliferasi, sehingga migrasi dan proliferasi sel-sel epidermal tidak terhambat. Hasil pengamatan dapat dilihat pada Tabel 2.

Tabel 2. Penilaian parameter pada hasil preparat hari ke-2 dan ke-8

\begin{tabular}{ccccc}
\hline \multirow{2}{*}{ Kelompok perlakuan } & Hari & \multicolumn{3}{c}{ Penilaian parameter } \\
\cline { 3 - 5 } Ke- & Fibroblas & Neovaskularisasi & Epitelisasi \\
\hline \multirow{2}{*}{ Kontrol Negatif } & 2 & + & ++ & - \\
Kontrol Positif & 8 & + & ++ & - \\
& 2 & +++ & ++ & - \\
P1 & 8 & + & + & - \\
& 2 & ++ & ++ & ++ \\
P2 & 8 & + & ++ & - \\
& 2 & + & +++ & - \\
P3 & 8 & + & ++ & ++ \\
& 2 & ++ & ++ & - \\
P4 & 8 & + & + & - \\
& 2 & ++ & ++ & + \\
P5 & 8 & + & + & + \\
& 2 & ++ & + & + \\
\hline
\end{tabular}

Keterangan :

$+\quad$ :Terdapat fibroblas, neovaskularisasi, dan epitelisasi

++ : Terdapat banyak fibroblas, neovaskularisasi, dan epitelisasi

+++ : Terdapat lebih banyak fibroblast dan neovaskularisasi

- : Tidak terbentuk epitelisasi

Pada salep kombinasi ekstrak daun mengkudu dan batang patah tulang mengandung beberapa senyawa metabolit sekunder seperti flavonoid, tannin dan saponin yang bekerja secara sinergis dalam membantu penyembuhan luka insisi dangkal dalam regenerasi sel. Flavonoid berperan dalam fase inflamasi, tanin berperan dalam proses angiogenesis atau neovaskularisasi (re-vaskularisasi) dan saponin bereperan dalam proses fibroblas yang akan menjadi epitel (re-epitelisasi) (Suprapto 2012; Soni \& Singhai, 2012; Sibi dkk., 2012).

Senyawa metabolit sekunder yang terdapat di dalam batang patah tulang dan daun mengkudu dapat ditentukan dengan metode skrining fitokimia. Senyawa metabolit sekunder yang dianalisis meliputi flavonoid, tanin dan saponin. Hasil skrining fitokimia batang patah tulang dan daun mengkudu dapat dilihat pada Tabel 3 dan Tabel 4. 
Tabel 3. Hasil uji fitokimia batang patah tulang

\begin{tabular}{ccc}
\hline Uji Fitokimia & Hasil & Keterangan \\
\hline Flavonoid & + & Berwarna Jingga \\
Tanin & + & Berwarna Biru Tua \\
Saponin & + & Terdapat Sedikit Buih \\
& & yang Stabil \\
\hline
\end{tabular}

Tabel 4. Hasil uji fitokimia daun mengkudu

\begin{tabular}{ccc}
\hline Uji Fitokimia & Hasil & Keterangan \\
\hline Flavonoid & + & Berwarna Jingga \\
Tanin & + & Berwarna Hijau \\
& & Kehitaman \\
Saponin & ++ & Terdapat Banyak Buih \\
& & yang Stabil \\
\hline
\end{tabular}

\section{KESIMPULAN}

Formulasi salep kombinasi ekstrak daun mengkudu dan batang patah tulang dapat memperbaiki histopatologi kulit pada luka insisi dangkal dalam penyembuhan luka pada tikus. Formulasi salep yang paling efektif adalah formulasi III dengan perbandingan ekstrak daun mengkudu dan batang patah tulang 0,75:0,25 yang terlihat dari penurunan jumlah fibroblas, penurunan neovaskularisasi menjadi vaskularisasi dan peningkatan proses epitelisasi (pembentukan sel epitel) secara signifikan (Tabel 2).

Pemanfaatan formulasi kombinasi salep ekstrak daun mengkudu dan batang patah tulang, berpengaruh terhadap regenerasi sel penyembuhan luka insisi dangkal pada tikus putih jantan yang melalui beberapa fase penyembuhan yaitu fase inflamsi, TNF- $\alpha$, revaskularisasi dan fase proliferasi, yang ditandai dengan ditemukannya fibroblas, neovaskularisasi dan epitelisasi secara histopatologi dalam 2 satuan waktu pengambilan.

\section{UCAPAN TERIMAKASIH}

Dengan selesainya penelitian ini, kami ucapkan terima kasih kepada Fakultas Matematika dan Ilmu Pengetahuan Alam Universitas Bengkulu atas fasilitas yang diberikan untuk membantu pelaksanaan penelitian ini.

\section{DAFTAR PUSTAKA}

Absor, U. (2006). Aktifitas Antibakteri Batang Patah Tulang (Euphorbia tirucalli Linn). Skripsi; Fakultas Matematika dan Ilmu Pengetahuan Alam Institut Pertanian Bogor, Bogor

Ahmad, A. J. (2009). Histoteknik Dasar. Jakarta: Fakultas Kedokteran Universitas Indonesia.
Akhtar, M. M., Srivastava, S., Sinha, P., Singh, K. D., Luqman, S., Tandon, S. \& Yadav, P. N. (2014). Antimicrobial Potential of Topical Formulasition Containing Essential Oil of Encalyptus citriodora Hook, Journal of Annals Phytomedicine; 3; 37-42.

Ambiyani, W. (2013). Pemberian Salep Ekstrak Daun Mengkudu Meningkatkan Proses Regenerasi Jaringan Luka pada Tikus Putih Galur Wistar jantan. Tesis; Fakultas Kedokteran Universitas Udayana Bali, Bali.

Broughton, I. I. G., Janis, J. E. \& Attiger, C. E. (2006). Wound Healing: An Overview. Plastic Reconstruction Surgery; 117; 1-32.

Dalimartha, S. (2003). Atlas Tumbuhan Obat Indonesia (Jilid 4). Jakarta: Pustaka Bunda.

Djamil, R., Wahyudi, P. S., Wahono, S. \& Hanari, M. (2012). Antioxidant Activity of Flavonoid from Anredera cordifolia (Ten) Steenis Leaves. International Research Journal of Pharmacy; 3; 241- 243.

Lawrence, W. T. \& Lowenstein, A. (2001). Wounds: Biology, Pathology, and Management. In: Norton JA, Bollinger RR, Chang AE, Lowry SF, Mulvihill SJ, Pass HI, Thompson RW (ed.). Surgery: Basic Science and Clinical Evidence; 221-236. New York: Springer-Verlag.

Nabilla, R. F. (2014). Pengaruh Pemberian Salep Ekstrak Daun Binahong (Anredera cordifolia (Tenore) Steenis) terhadap Re-epitelisasi pada Luka Bakar Tikus Sprague Dawley. Skripsi; Universitas Islam Negeri Syarif Hidayatullah, Jakarta.

Rakhim, M. (2016). Formulasi Sediaan Salep Minyak Atsiri Kemangi (Ocimum basilicum L.) dan Uji 
Aktivitas Antibakteri terhadap Staphylococcus aureus. Skripsi; Fakultas Farmasi Universitas Muhammadiyah Surakarta, Surakarta.

Rasal, V. P., Sinnathambi, A., Ashok, P. \& Yeshmaina, S. (2008). Wound Healing dan Antioxidant Activities of Morinda citrifolia Leaf Extract in Rats. Iranian Journal of Pharmacology \& Therapeutics; 7; 49-52.

Putra, F. M. (2016). Penggunaan Chlorhexidine 0,2\% dengan Povidone Iodine $1 \%$ Sebagai Dekontaminasi Mulut Terhadap Kolonisasi Staphylococcus aureus Pada Pasien Pasca Operasi Anestesi Umum. Nurse Line Journal; 1; 177.

Sentat, T. \& Permatasari, R. (2017). Uji Aktivitas Ekstrak Etanol Daun Alpukat (Persea americana Mill.) terhadap Penyembuhan Luka Bakar pada Punggung Mencit Putih Jantan (Mus musculus). Jurnal Ilmiah Manuntung; 1; 100-106.

Setyoadi \& Sartika, D. D. (2010). Efek Lumatan Daun Dewa (Gynura segetum) dalam Memperpendek Waktu Penyembuhan Luka Bersih pada Tikus Putih. Jurnal Keperawatan Soedirman; 5; 127-135.
Sibi, G., Chatly, P., Adhikari, S. \& Ravikumar, K. R. (2012). Phytoconstituent and Their Influence Antimicrobial Properties of Morinda citrifolia L. Research Journal of Medicinal Plant; 6; 441-448.

Sjamsuhidajat, R. \& Jong, W. D. (2010). Buku Ajar Ilmu Bedah (Edisi 3). Jakarta: EGC.

Soni, H. \& Singhai, A. K. (2012). A Recent Update of Botanicals for Wound Healing Activity. International Research Journal of Pharmacy; 3; 1-7.

Suprapto, A. K. (2012). Efek Salep Ekstrak Metanoldan Salep Serbuk Daun Sosor Bebek (Kalanchoe pinnata (Lamk)) terhadap Penyembuhan Luka Sayat pada Mencit. Tesis; Fakultas Kedokteran Universitas Kristen Maranatha, Bandung.

Thakur, R., Jain, N., Pathak, R. \& Sandhu, S. S. (2011). Practices in Wound Healing Studies of Plants. Evidence-based Complementary and Alternative Medicine; 2011; 1-17.

Ueno, C., Hunt, T. K. \& Hopf, H. W. (2006). Using Physiology to Improve Surgical Wound Outcomes. Plastic and Reconstructive Surgery; 117; 59S-71S. 